\title{
A Social Entrepreneurship Case Study of the "Pertubuhan Kebajikan Anak Yatim Islam Segamat" Orphanage in Malaysia
}

\author{
Saunah Zainon ${ }^{1}$, Rina Fadhilah Ismail ${ }^{2}$, Soo Kum Yoke ${ }^{3}$, Haryati Ahmad ${ }^{4} \&$ Nurulzulaiha Sa'udah @ Suhadak ${ }^{5}$ \\ ${ }^{1}$ Faculty of Accountancy, Universiti Teknologi MARA Cawangan Johor, Segamat, Johor, Malaysia \\ 2 Faculty of Accountancy, Universiti Teknologi MARA Cawangan Selangor, Bandar Puncak Alam, Selangor, \\ Malaysia \\ 3 Academy of Languages Studies, Universiti Teknologi MARA Cawangan Negeri Sembilan, Rembau, Negeri \\ Sembilan, Malaysia \\ ${ }^{4}$ Academy of Languages Studies, Universiti Teknologi MARA Cawangan Johor, Segamat, Johor, Malaysia \\ 5 Senior Lecturer, Faculty of Computer and Mathematical Sciences, Universiti Teknologi MARA Cawangan Johor, \\ Segamat, Johor, Malaysia \\ Correspondence: Saunah Zainon, Associate Professor, Faculty of Accountancy, Universiti Teknologi MARA \\ Cawangan Johor, Segamat, Johor, Malaysia. E-mail: sauna509@johor.uitm.edu.my
}

Received: May 12, 2020

doi:10.5430/ijfr.v11n3p162
Accepted: June 20, 2020

Online Published: June 29, 2020

URL: https://doi.org/10.5430/ijfr.v11n3p162

\begin{abstract}
Most orphanages in Malaysia are run by means of charitable donations. However, the donations and contributions collected are usually not regular or one-off. This has led to orphanages being in a run-down state and ill-equipped. The care given to orphans is important as part and parcel of their human rights to be treated and given a fair chance of living with the rest of the human race. As such, this paper aims to investigate the role of social entrepreneurship in providing care for orphans. Particularly, the paper will focus on an orphanage - "Pertubuhan Kebajikan Anak Yatim Islam Segamat" (PKAYIS) which is located in the state of Johor. PKAYIS has provided shelter for 68 orphans and through charitable donations has been running successfully since 1983. The orphanage has been able to successfully bring up orphans who have succeeded academically and found successful careers in life. Based on the theoretical framework on social entrepreneurship and orphans, observation methods and interviews were carried out to supply relevant information and data for the study. This paper will provide some insights on how social entrepreneurship affects the society and would be beneficial for policy makers interested in adopting social entrepreneurship as a mean of care for orphans.
\end{abstract}

Keywords: entrepreneurship, interviews, orphans, participation observation, social values

\section{Introduction}

Funds and resources for non-profit organizations (NPOs) in Malaysia are quite challenging to secure. More so when the charity organizations such as orphanages are small institutions with social missions and are not publicly traded. These organizations' survival mostly depends on donations from the public or through income-generated activities by the organizations themselves. Besides that, these charity organizations also depend on funds from various sources, including government grants, membership fees as well as commercial activities for their survival. These funds or resources are needed for the organizations to run their day-to-day operations in order to align with their organizational purpose. There is a need for good management and financial practices of the orphans' welfare for their basic necessity, education and security as a whole (Izzatul et al., 2018). NPOs with heavy reliance on government grants and philanthropic aids are not sustainable especially in the wake of economic downturns (Stecker, 2016).

Whilst business organizations have their stability of income through the business that they are doing, charity organizations do not. However, by means of social entrepreneurship of NPOs, they may be able to sustain their finances. Social entrepreneurship is a business that can solve social problems. The money derived from the business can be used to help others, particularly the members of the organizations. The key point is that a social enterprise will always have social impact purpose even though it is a means for generating revenues or income. 
This research paper has thus far provided a general overview of the case study. In the consecutive sections, the literature review will be presented followed by the methodology for the study and the reports on findings and the conclusions.

\section{Literature Review}

\subsection{Social Enterprise Operations}

By definition, a social enterprise is an operator with the purpose of providing a social impact. This is in contrast to a business enterprise whose main purpose involves profit making for the business owners. Ridley-Duff and Bull (2015) described social enterprise as part of the economic system. This system is divided into three parts which are private sector, public sector and social economy. The private sector is profit oriented while the public sector is driven by a planned provision for the public. Social economy puts social well-being foremost and social enterprise falls under this part of the economic system.

Mair and Noboa (2006) stated that social and economic wealth creations under entrepreneurial initiatives are not new. However, relatively little are known about their dynamics and processes. In actuality, Social Entrepreneurship (SE) has been said to have become ubiquitous in recent times. It involves innovative approaches that address issues related to education, environment, fair trade, health and human rights. It helps in the sustainable development of countries.

From a sociological perspective, Yilmaz and Yilmaz (2019) asserted that the concept of SE seems to be in the field of interest of business management and behavioural intelligence. SE has a close relationship with the society and deals with creating solutions for social problems. This is done by creating social value through the placing of social missions as the focal point of the operation. The aim is to have social transformation that reaps social benefits. In a study by Mirvis and Googins (2018), employees were tasked with engagements of social activities either as social innovators in the company or as co-creators with external social entrepreneurs. Thus, they were tasked with building partnerships with other businesses, NGOs and government agencies to reach out to the society. This helped in the creation of social awareness that focused on social economy.

\subsection{Social Value and Social Benefits}

Gray, Kirkwood, Monahan and Etemaddar (2018) examined the internal factors dealing with effective opportunity identification in a social enterprise. The study aimed at assessing controllable factors that can produce sustainable outcomes. The respondents were from the Tongan National Youth Congress which is an organization that helps young people develop micro enterprises. Findings from the study indicated that there is a need for creative entrepreneurial and marketing approaches for sustainability. Thus, the study suggests that social value and social benefits can be attained only with initiatives of creativity and marketing strategies.

Mahfuz, Razzaque, Liaw, Ray and Hasan (2018) asserted that many NGOs are showing increasing interest in social business models to help minimize social problems. Their study identified five key aspects of social business such as business's mission and outcomes, characteristics, operation, resource utilization and environmental considerations. Looking at social business interventions in a developing country, Bangladesh, and based on the five key aspects of social business, it was found that social business is the most efficient way to sustainably maximize social benefits and minimize social issues like poverty. Hence, social enterprises can contribute to social values and provide social benefits. In the long run, this could spur economic growth.

\section{Methodology}

Since information about NPOs is often sparse and hardly obtainable, this study adopted a qualitative research method. Qualitative techniques used in this study for gathering data include observations and interviews (Neuman, 2003). In addition, secondary data in the form of stand-alone annual reports prepared by the organizations were studied and the relevant information was collected.

\subsection{Field Visits, Observations and Interviews}

The researchers visited the offices of the organization "Pertubuhan Kebajikan Anak Yatim Islam Segamat" (PKAYIS) which is located in Segamat, Johor, Malaysia and also the farms in which the organization operates the seedling and harvesting of vegetables and oil palm plantations. PKAYIS reduces the burden of its operation by growing and selling their crops for the benefits of the orphans ensconced by it. The staff (seven paid staff) and committee members (25 committee members) of PKAYIS ensure the maximum full utilization of the organizational land. Every aspect of farming supply chains, from purchase of soil to marketing is taken care by the staffs and committee members in charge. The vegetable farms are operated on the land surrounding the PKAYIS building, whilst the approximately 50-acres oil palm plantations are located within a 10-kilometre radius from PKAYIS premise. Two site visits were made at the 
beginning of the year and five site visits were made end of the year. During the site visits, the PKAYIS General Secretary and committee members who were in charge of the farms and the plantations were interviewed to provide information on their roles and commitments towards ensuring the success of the farms and the plantations. There were three interviewees involved in this study. They were those responsible on the welfare, activities and operations carried out by the orphanage throughout the year. They were also mandated in reducing problems associated with and establishing future expectations of the orphanage. The interviews were recorded with the permission of the interviewees.

\subsection{Residences}

The orphanage operated by PKAYIS, is able to accommodate 62 orphans at a time. With the two-block of hostel buildings, it can admit 31 male and female orphans respectively. The requirements for orphans to stay there are: aged between ten and 18 years old, and must still be schooling. As at 2 January 2018, there were 62 registered orphans residing at PKAYIS. Orphans are those children whose fathers have passed away.

\subsection{Case Study Observations}

This study focuses on PKAYIS orphanage as a sample of NPOs classified under the category of social welfare. There are about 50 orphanages all over Malaysia; however, for the purpose of an in-depth study, PKAYIS orphanage was chosen as a sample to represent the Southern Zone of Peninsular Malaysia. Other than that, PKAYIS was one of the organizations approached by the researchers that were willing to cooperate and participate in this study. Observations in field research often involve detailed and tedious work (Locke et al., 2000). However, it can provide a close approximation to what has occurred and a permanent record that others can review. Furthermore, site visits were made to interview the persons in charge of running the orphanage and to observe the conditions of the orphans and the homes itself.

\subsection{Interviews}

Semi-structured interview schedules were used in data gathering methods. The dependability of the data was promoted when the researchers described and documented the research process in detail, enabling other researchers to replicate the study (Shenton, 2004). The interview data were then analysed in line with Creswell's (2009) qualitative data thematic analysis. Interviews were made to three persons directly in charge of the orphans, the orphanage as well as the farm and the oil palm plantations. The confirmability of the study is ensured through recording and transcribing the interviews and documenting the interviewees' responses.

\subsection{Content Analysis}

During the visits to PKAYIS orphanage, the researchers managed to collect stand-alone annual reports of PKAYIS for the years 2016 and 2017. The annual report for the year 2018 was still incomplete at the time the data were collected. The reports contained the President's message, the activities, background of the orphans and financial aspects of the orphanage such as the Statement of Receipts and Payments, Balance Sheet, Cash Flows, Notes to the Accounts and the Auditor's Report. Although there are challenges in adopting qualitative content analysis (Kracauer, 1952), the technique was still applied for this study because it can be used to describe an approach of systematic, rule-guided qualitative text analysis, which tries to preserve some methodological strengths of quantitative content analysis and widen them to a concept of qualitative procedure (Mayring, 2000).

\section{Findings}

The first section of the findings outlines the biographical profiles of the participants in this study. This is followed by the discussion of the themes from the data collected.

\subsection{Biographical Profiles}

The research sites under this study were the vegetable farms, and the oil palm plantations which are located in two zones. The vegetable farms are situated around the one-acre land surrounding the PKAYIS building. The vegetables are normally picked up and transferred to the orphanage's kitchen for the children's consumption. The vegetables are seldom sold to outside market; it mostly benefits the children of PKAYIS. The oil palm plantations of Zone 1 consists of three lots of land i.e. Lot No. 1121, Lot No. 8089 and Lot No. 8664 totalling 23.79 acres, located at Gemereh, Bukit Kepong and Mukim Jementah respectively. On the other hand, Zone 2 consists of only one lot i.e. Lot No. 8514 for 14.45 acres. The two zones of oil palm plantations have already produced palm oil, and generated sales of RM12,682.53 for the years 2016 to 2017 and RM6,839.25 for the year 2018. The sales from these plantations are used to finance the day-to-day operations of PKAYIS, in particular for the necessity of the orphans. There are another three lots of oil palm lands, i.e. Lot No. 878, Lot No. 1468 and Lot No. 681 which are newly cleaned and levelled for the 
purpose of fertilizing and seedling the palm oil. In other words, no income has been generated from these three lots since the lots were just operated at the end of December 2017 and it will take at least two years for the oil palms to grow and produce oil palm yield.

As per vegetable farms surrounding PKAYIS, the produce is mostly for the orphans and only the excess will be sold to the community around PKAYIS. The sale proceeds per year from the sales of vegetables was approximately RM3,000 for the years 2016-2017, and RM800 for the year 2018.

\subsection{Respondents}

Interviewee A-1, an administrator of PKAYIS who fully takes care of the welfare of the children, was interviewed for three times. Another interviewee, Interviewee B-2, is one of the committee members in charge of the vegetable farms. He was interviewed two times during the period of this study. Interviewee C-3 was interviewed twice regarding the oil palm land plantations.

\subsection{Themes and Sub-themes of Findings}

\section{Theme 1: Social Entrepreneurship of NPOs as a Means of Care for PKAYIS Orphans}

Interviewee B-2 of the vegetable farms surrounding PKAYIS explained as follows:

"After seedling and fertilizing the vegetables, we will wait for the picking time, and all the vegetables will be sent to kitchen for them to prepare the vegetables for the children's breakfast, lunch or dinner. The balance of the vegetables will be sold and the sale proceed will be kept and set aside to buy seeds for the next planting projects."

A key informant of Interviewee C-3 confirmed that and agreed that:

"The sale proceeds generated is not for consumption of those who operates it for administration but for the main purpose for the orphans of PKAYIS."

The produce is also sold to the staff of PKAYIS and the community around the orphanage. The vegetables are sold directly from the farm site. A closer look towards the implementation of social entrepreneurship in NPOs are the Bamboo School, Thailand, Ruvivo honey harvesting in Zimbabwe and Mataga Nutrition gargen projects and Sekem projects in Egypt. The sale proceeds from the sale of the business are used to finance and fund the operation of the institution such as schools, education and training centres. If there is profit from the sale of vegetables, it will be used to provide other necessities of the orphans such as clothes, education, security or healthcare. The purpose of selling the vegetables is captured in the words of a key informant who said: "We help the children based on their needs such as health, education, security, clothes and medicine."

\section{Theme 2: Social Value and Social Benefits}

The income generated from the above projects of vegetable farms and oil palm plantations are in line with the core purpose of social entrepreneurship to create social values for public good (Austin et al., 2006). Interviewee C-3 stated:

"For us at PKAYIS, income generated from the projects is not important. The most important aspect is to make sure the orphans at PKAYIS are well taken care of and protected in terms of their security and healthcare."

As above, the respondent agreed that social value is well-noted and realized through the social benefits that accrued to the orphans. The surplus generated from income-generating projects places a great contribution for the orphan's charity and welfare. It is shown that the orphans staff members of PKAYIS are affected by the income-generating projects and this is proven through positive changes in the form of better lives of the orphans. The role of income generating projects has also been seen as a catalyst for social protection.

\section{Theme 3: Social Protection}

Interviewee A-1 mentioned that:

"As far as orphans are concerned, the children are given maximum priority of their basic necessity and education. The orphans are able to access education through fund supports from income-generating projects. The income generating projects from oil palm plantation were able to fund school fees for a total of 62 children in both primary (6 children) and secondary schools (56 children). These children were not only able to attend school but they were sent for tuitions (extra classes) and were given free access of password for Score A. Score A is a programme or system developed for the students to have an interactive learning activities through online system. Other than for education, the children are to receive their pocket money every day for their food at schools and they receive their uniforms their first day of the school term."

The above scenario shows that income generating projects strive for a long-term effects and benefits for the children. 
This is mostly due to flexible governance and control, whereby the staff and the committee members of the organization itself, i.e. PKAYIS, contributed the best form of social value and benefits they can deliver. The orphans can be considered very lucky because their social value and benefits of high quality and sustainability of their needs are fulfilled.

\section{Theme 4: Needs of Orphans}

The income generating projects play an important role in enabling the orphans to meets its needs. A key informant B-2 said that: "We want to ensure the needs of orphans are fulfilled because they have their needs and it is their rights to have all the needs. The orphans are the community's responsibilities when their father passed away. Their needs concern of the whole community."

Interviewee B-2 also agreed that because of the income generating projects initiated and run by PKAYIS, the responsibility and ownership towards income generating projects placed as an important role towards the success of the projects.

\section{Conclusions}

The responsibility to care for the needs of orphans has shifted from being fully-funded by the government to the members of the organization to mobilize their own resources (Katungu and Lombard, 2015). This is called social entrepreneurship for NPOs. It is a huge challenge to implement best practices of social entrepreneurship for NPOs in Malaysia since social entrepreneurship is still at infant stage in this country. Furthermore, there is no existing benchmark or specific governance standards for social entrepreneurship of the NPOs.

The practice of social entrepreneurship by PKAYIS in the form of income generation through the vegetable farms and oil palm plantations has proven to be impactful. As a means of caring for the orphans, the vegetables grown around the orphanage are served to the orphans themselves and the money earned from selling the excess vegetables is used to re-stock the seeds for future vegetable farming. In addition, in terms of social values, benefits and protection, the social entrepreneurship projects and the income gained from them have contributed to the well-being, security and education of the orphans. Thanks to the initiatives of creativity and marketing strategies (Gray, Kirkwood, Monahan \& Etemaddar, 2018), the children at PKAYIS orphanage are not only able to consume freshly picked vegetables for their meals, but they also manage to pay for the school and tuition fees, and are able to access the Score A online educational system. In other words, the orphans' needs are fulfilled to the best ability of the PKAYIS staff and the committee members through the adoption of social entrepreneurship.

\section{References}

Altinay, L., Sigala, M., \& Waligo, V. (2016). Social value creation through tourism enterprise. Tourism Management, 54, 404-417. https://doi.org/10.1016/j.tourman.2015.12.011

Austin, J., Stevenson, H., \& Wei-Skillern, J. (2006). Social and commercial entrepreneurship: Same, different or both? Entrepreneurship Theory and Practice, 30(1), 1-22. https://doi.org/10.1111/j.1540-6520.2006.00107.x

Creswell, J. W. (2009). Research design: Qualitative, quantitative and mixed-method approaches. Thousand Oaks, United States: SAGE Publications Inc.

Forsyth, D. R. (2006). Group dynamics. Pacific Grove, CA: Brooks/Cole.

Gray, B., Kirkwood, J. J., Monahan, E., \& Etemaddar, M. (2018). Internal factors influencing effective opportunity identification in a Tongan social enterprise. Journal of Small Business \& Entrepreneurship, 1-25. https://doi.org/10.1080/08276331.2018.1459015

Izzatul, U. R., Nor Farhana, S., Alhana, O., Sharina, M. S., Mohamad Ishak, M. I., \& Norlaila, M. M. (2018). Challenges in managing an orphanage: A perspective of orphanage operator in the state of Pahang. Global Business \& Management Research, 10(3), 150-159.

Katungu, W., \& Lombard, A. (2015). The contribution of social entrepreneurship in meeting the needs of orphans in the Mberengwa District, Zimbabwe. Social Work/Maatskaplike Werk, 52(2), 188-207. https://doi.org/10.15270/52-2-500

Kracauer, S. (1952). The challenge of qualitative content analysis. Public Opinion Quarterly, 16, 631-642

Locke, L. F., Spirduso, W. W., \& Silverman, S. J. (2000). Proposals that work: A guide for planning dissertations and grant proposals. Thousand Oaks, CA: Sage.

Mahfuz Ashraf, M., Razzaque, M. A., Liaw, S. T., Ray, P. K., \& Hasan, M. R. (2018). Social business as an 
entrepreneurship model in emerging economy: Systematic review and case study. Management Decision. https://doi.org/10.1108/MD-04-2017-0343

Mair, J., \& Noboa, E. (2006). Social entrepreneurship: How intentions to create a social venture are formed. In Social entrepreneurship (pp. 121-135). Palgrave Macmillan, London: Springer.

Mayring, P. (2000). Qualitative content analysis. Forum Qualitative Sozialforschung/ Forum: Qualitative Social Research, 1(2), Art. 20. https://doi.org/10.17169/fqs-1.2.1089

Mirvis, P., \& Googins, B. (2018). Engaging employees as social innovators. California Management Review, 60(4), 25-50. https://doi.org/10.1177/0008125618779062

Mirvis, P., Herrera, M. E. B., Googins, B., \& Albareda, L. (2016). Corporate social innovation: How firms learn to innovate for the greater good. Journal of Business Research, 69(11), 5014-502. https://doi.org/10.1016/j.jbusres.2016.04.073

Neuman, W. L. (2003). Social research methods: Qualitative and quantitative approaches. Boston: Allyn and Bacon.

Ridley-Duff, R., \& Bull, M. (2015). Understanding social enterprise: Theory and practice. UK: SAGE.

Sandelowski, M. (2010). What's in a name? Qualitative description revisited. Research in Nursing and Health, 33(1), 77-84. https://doi.org/10.1002/nur.20362

Saunah, Z., Marshita, H., Nadzira, Y., \& Ruhaya, A. (2013). Annual reports of non-profit organizations (NPOs): An analysis. Journal of Modern Accounting and Auditing, 9(2), 183-192.

Saunah, Z., Ruhaya, A., \& Bee Wah, Y. (2014). An empirical study on the determinants of information disclosure of Malaysian non- profit organizations. Asian Review of Accounting, 22(1), 35-55. https://doi.org/10.1108/ARA-04-2013-0026

Shenton, A. K. (2004). Strategies for ensuring trustworthiness in qualitative research projects. Education for Information, 22(2), 63-75. https://doi.org/10.3233/EFI-2004-22201

Stecker, M. J. (2016). Awash in a sea of confusion: Benefit corporations, social enterprise, and the fear of "greenwashing". Journal of Economic Issues, 50(2), 373-381. https://doi.org/10.1080/00213624.2016.1176481

Tooley, S., \& Guthrie, J. (2001). Performance accountability disclosures in annual reports: An application in the New Zealand compulsory school sector. Paper presented at the Third Asian Pacific Interdisciplinary Research in Accounting Conference, Adelaide.

Trussel, J. M., \& Parsons, L. M. (2007). Financial reporting factors affecting donations to charitable nonprofit organizations. Advances in Accounting, 23, 263-285. https://doi.org/10.1016/S0882-6110(07)23010-X

Yilmaz, A., \& Yilmaz, H. U. (2019). Social value and sociological perspective on social entrepreneurship. In Creating business value and competitive advantage with social entrepreneurship (pp. 21-47). Istanbul, Turkey: IGI Global. 